\title{
A REVIEW OF THE FORMATION AND BINDING OF 5 $\alpha$-DIHYDROTESTOSTERONE IN THE MECHANISM OF ACTION OF ANDROGENS IN THE PROSTATE OF THE RAT AND OTHER SPECIES
}

\author{
W. I. P. MAINWARING \\ Androgen Physiology Department, Imperial Cancer Research Fund, \\ Lincoln's Inn Fields, London WC2A 3PX
}

\section{INTRODUCTION}

It is now 60 years or so since reliable medical records have been kept and, despite dramatic fluctuations in the incidence of certain forms of human cancer, abnormalities in the growth of the prostate gland have consistently been responsible for the third highest proportion of deaths from this disease. As so lucidly described by Dorfman \& Shipley (1956) in the histological introduction to their reference treatise, interest in the androgens or, perhaps more accurately, testicular secretions, began through the inquisitiveness of the ancients in sexual potency and fertility rites, continued somewhat intermittently through the Middle Ages and was finally set upon a more scientific plane of enquiry through the classical studies of Pott, Hunter, Berthold and Brown-Séquard. What really emerged from these studies was that testicular secretions were capable of controlling the growth of organs distant from the testis, including the prostate gland. After a favourable period for investigating the synthesis and qualitative nature of testicular secretions, leading to the isolation of testosterone, the advent of the age of 'molecular biology' heralded a change in emphasis in this area of endocrinological research. Rather than describing androgen effects in terms of morphology or physiological response, it has become more pertinent and stimulating to approach the problem from the standpoint of the early interaction of androgens with androgen-responsive tissues and to attempt to unravel the early metabolic events set in train by these initial interactions. Irrespective of the time of enquiry, the elucidation of the mechanism of action of androgens has always represented a daunting undertaking. One may, however, always gain inspiration from the dictum of Francis Bacon:

"If a man will begin with certainties, he shall end in doubts,

But if he will be content to begin with doubts, He shall end in certainties." (Advancement of Learning, book I; 1605.)

\section{THE PRESENT VIEW OF THE MECHANISM OF ACTION OF ANDROGENS IN THE RAT VENTRAL PROSTATE}

The current view of the mechanism of action of androgens in rat prostate is 


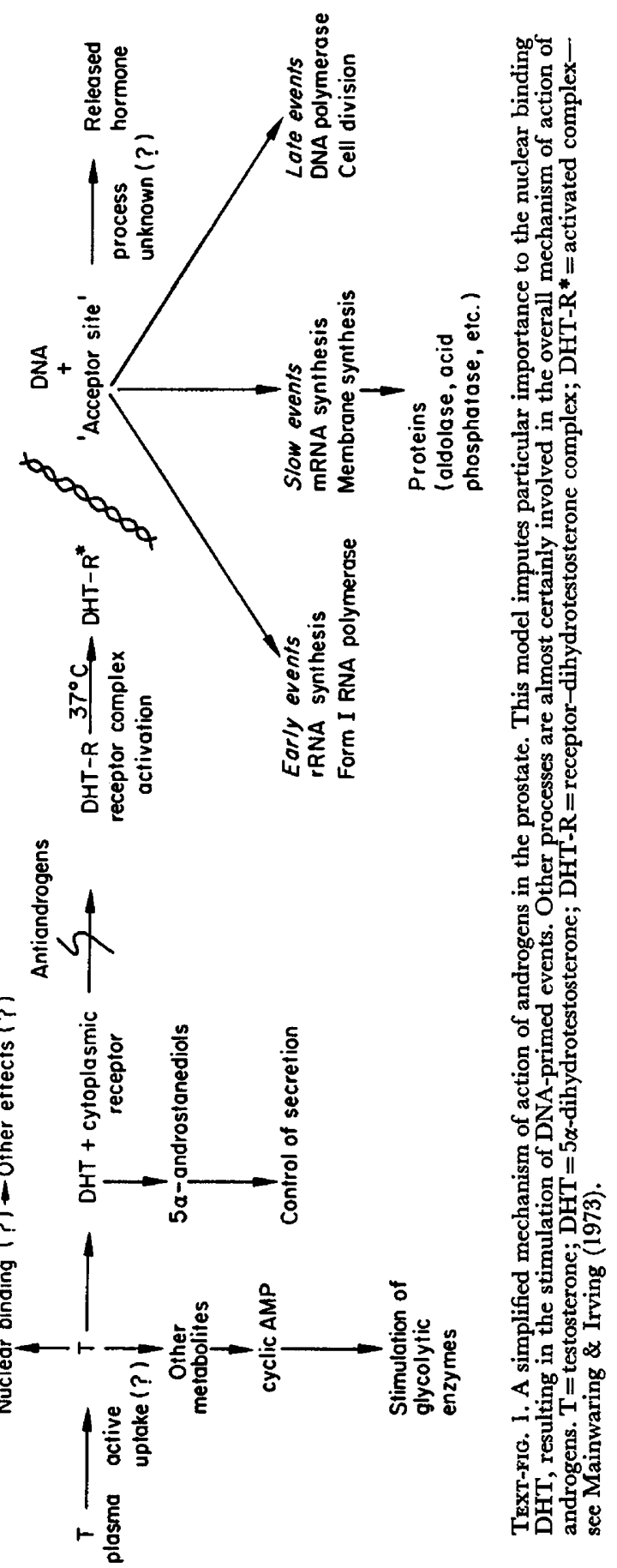


presented in Text-fig. 1. This is a summary of experimental findings from many sources (reviewed by King \& Mainwaring, 1974) and from the author's laboratory. The critical features of the proposed scheme are the formation of $5 \alpha$-dihydrotestosterone within the prostate, its binding to a cytoplasmic androgen receptor and the translocation of the resultant complex into chromatin. Many features of the proposed scheme remain the centre of some debate and further comment is warranted.

\section{Androgens and their binding in plasma}

In many species, but not the rat or ruminants (Murphy, 1968; de Moor et al., $1969)$, testosterone is bound with high affinity to the sex steroid-binding $\beta$ globulin (SBG). When SBG is not present, the plasma binding of testosterone is probably mediated by the corticosteroid-binding $\alpha_{2}$-globulin (CBG; Murphy, 1968). Precise data are not available for the rat, but in man at least only trace amounts of $5 \alpha$-dihydrotestosterone are present in plasma (Furuyama et al., 1970; Ito \& Horton, 1970; Tremblay et al., 1970) and this is bound with an even higher affinity to SBG than testosterone (Kato \& Horton, 1968; Vermeulen \& Verdonck, 1968). This makes it highly unlikely that peripheral $5 \alpha$-dihydrotestosterone is a major androgenic stimulus to the accessory sexual glands in animals in which SBG is present. Tremblay et al. (1972) thoroughly investigated the source of $5 \alpha$-dihydrotestosterone in peripheral blood, and concluded that one third is derived from plasma-borne precursors and the remainder directly secreted by the testis. The situation is far less clear in, say, the rat in which CBG is the principal binder of androgens in the plasma; there is a paucity of data on the relative affinity of CBG for $5 \alpha$-dihydrotestosterone. On the basis of recent work in this laboratory (Mainwaring \& Mangan, 1973), rat plasma does not contain detectable amounts of $\left[{ }^{3} \mathrm{H}\right] 5 \alpha$-dihydrotestosterone after the administration of $\left[{ }^{3} \mathrm{H}\right]$ testosterone at times when the formation of $\left[{ }^{3} \mathrm{H}\right]$ $5 \alpha$-dihydrotestosterone in the prostate is at a maximum. It seems likely, therefore, that $5 \alpha$-dihydrotestosterone is principally synthesized within the prostate and not derived from other sources via the peripheral circulation.

Neither SBG nor CBG can be considered as true androgen receptors. The plasma proteins, for example, are unable to fulfil one characteristic function of the receptor proteins, namely the transfer of $5 \alpha$-dihydrotestosterone into chromatin in cell-free systems (Mainwaring \& Peterken, 1971; Mainwaring \& Irving, 1973).

\section{Uptake of androgens into the prostate}

This process has regrettably received little attention. However, the influence of the prior administration of certain non-radioactive steroids to castrated animals before the injection of a tracer dose of $\left[{ }^{3} \mathrm{H}\right]$ testosterone on the entry of radioactivity into the rat prostate suggests that a specific entry mechanism exists for the androgens (Mainwaring et al., 1974a). From elegant studies on human and canine prostates maintained in vitro by a superfusion technique, Giorgi et al. $(1972,1973)$ have obtained far more striking evidence in support of a specific carrier mechanism for the transport of androgens into the accessory sex glands. Additional studies are clearly desirable, particularly since impair- 
ment of the uptake of androgens could provide a chemotherapeutic means for arresting abnormal patterns of growth in the prostate.

\section{The exit process for $5 \alpha$-dihydrotestosterone from the nucleus}

Although it must be conceded that the construction of experimental systems suitable for monitoring the release of $5 \alpha$-dihydrotestosterone from chromatin is exceedingly difficult, much more attention should be devoted to this problem. All investigators, including the present author, have been somewhat obsessed with uptake and retention processes, and this equally important exit mechanism warrants urgent study.

\section{The metabolism of androgens in the prostate}

After a very confused early history (see King \& Mainwaring, 1974), evidence now points to the all-important formation of $5 \alpha$-dihydrotestosterone within the prostate gland. This steroid-reductive machinery is sufficiently powerful in the rat prostate to convert many less potent androgens, such as androsterone and androstenedione, to $5 \alpha$-dihydrotestosterone (Bruchovsky, 1971; Roy et al., $1972 \mathrm{a}, \mathrm{b})$. The $5 \alpha$-reductase utilizes reducing equivalents of NADPH in a unique way for direct reduction of the $\Delta_{4,5}$ bond and the system is thermodynamically irreversible. Accordingly, inactivation of $5 \alpha$-dihydrotestosterone must involve changes in the oxygen functions at $\mathrm{C} 3$ or $\mathrm{C} 17$ and not dehydrogenation at C5. A wide spectrum of $5 \alpha$-androstanediols are also formed in the prostate gland but there is no convincing evidence that they are selectively accumulated in nuclear chromatin, as is $5 \alpha$-dihydrotestosterone. This indicates the particular importance of the C3 keto group and the hydroxysteroid dehydrogenases in controlling the formation and ultimate intracellular binding sites for important metabolites of testosterone.

\section{Binding of androgens other than $5 \alpha$-dihydrotestosterone in the prostate}

It would be erroneous to surmise that only the binding of $5 \alpha$-dihydrotestosterone is of importance in the prostate gland; it simply remains the best understood binding process demonstrable in accessory sex glands. Following preliminary investigations by Unhjem \& Tveter (1969), important observations by Rennie \& Bruchovsky (1972) indicate that both cytoplasmic and nuclear binding of testosterone occurs in the prostate. It is of great interest to ascertain whether the protein complexes containing either testosterone or $5 \alpha$-dihydrotestosterone occupy similar or even identical sites within chromatin. The binding of different receptor complexes in chromatin could provide androgen-dependent tissues with a subtle mechanism whereby the genetic apparatus could be selectively activated by different androgens. The biological relevance of the nuclear binding of testosterone, however, remains to be unequivocally established. Baulieu et al. (1971) demonstrated the presence of saturable and high-affinity binding sites for $5 \alpha$-androstane- $3 \beta, 17 \beta$-diol in prostate microsomes and this may be germane to their earlier proposal (Baulieu et al., 1968; Roy et al., 1972a, b) that $5 \alpha$-androstanediols may specifically regulate the secretory process in the prostate whereas $5 \alpha$-dihydrotestosterone controls cell division and other 
androgen-mediated processes triggered by nuclear as against extra-nuclear binding of androgens.

\section{The putative 'activation' of cytoplasmic receptor complexes}

It is well known that the nuclear binding of $5 \alpha$-dihydrotestosterone is a temperature-dependent process (Anderson \& Liao, 1968; Mainwaring, 1971) which cannot proceed readily at $0^{\circ} \mathrm{G}$. As extensively reviewed by King \& Mainwaring (1974), evidence from a diversity of hormone-sensitive systems alludes to the importance of a temperature-dependent 'activation' or change in configuration of cytoplasmic receptor complexes which facilitates receptor binding in the nucleus. Mainwaring \& Irving (1973) presented certain evidence favouring such a phenomenon in the prostate. Current studies are all performed on impure receptor preparations and it cannot be unequivocally stated that the 'activation' process is an intrinsic property of the receptor protein. Changes in physicochemical properties under these conditions could be attributed equally well to proteolytic activity. Failure to achieve 'activation' in the presence of well proven protease inhibitors such as phenylmethylsulphonylfluoride would clarify this issue.

\section{The acceptor hypothesis}

In cell-free systems based either on nuclei (Fang \& Liao, 1969a) or chromatin (Mainwaring \& Peterken, 1971), binding of androgen receptor complexes was reported to be more extensive into DNA-containing subcellular fractions derived from androgen-dependent tissues. This led to the formulation of the 'acceptor' hypothesis which essentially states that nuclei from androgendependent cells characteristically contain structural elements that enhance the retention of receptor complexes. Mainwaring \& Peterken (1971) concluded that although the receptor complex was probably bound to DNA, binding specificity was imparted to the process by non-histone proteins associated with chromatin. Liao et al. (1973) favour nuclear-associated RNA particles as the acceptor molecules, these being akin to the RNA-containing informosomes described by Georgiev (1972). There is no evidence that the pentose moiety imparts specificity to the binding of receptor complexes to nucleic acid structures (King, 1972), and hence the validity of the acceptor hypothesis requires more critical appraisal. Caution must be heeded in attributing biological significance to certain forms of nuclear-associated RNA since these can possibly be preparative artefacts (Artman \& Roth, 1971; Heyden \& Zachau, 1971) although this does not seem true in the present case. It would seem possible, however, that Liao et al. (1973) were in fact looking at the process by which receptors leave the nucleus rather than the process by which they are retained. Movement from nucleus to cytoplasm is a feature of informosomes. Clearly more work is required to determine the nature of the acceptor molecule with more precision.

\section{Androgenic responses not mediated by the receptor system}

On currently available evidence, it would appear fallacious to attribute all biochemical responses in the prostate to the initial formation of $5 \alpha$-dihydrotestosterone-receptor complexes. When it was found that certain glycolytic 
enzymes could be stimulated equally extensively by the administration of testosterone or cyclic AMP, in vivo, it was suggested that hormonal activation of the adenyl cyclase system was of considerable importance in the androgenic response (Singhal et al., 1971). This was an overstatement of the case, for it was subsequently established that cyclic AMP-stimulated events in the prostate are exceedingly restricted in number, concerning essentially only glycolytic enzymes (Mangan et al., 1973). Furthermore, the cyclic AMP-mediated responses could not be countered by the anti-androgens, BOMT or cyproterone acetate. In no sense can cyclic AMP be said to mimic extensively the effects of testosterone on the prostate.

\section{SYNTHETIC COMPOUNDS CAPABLE OF NEGATING THE EFFECTS OF ANDROGENS ON THE PROSTATE}

In many clinical disorders, the use of anti-androgens or compounds able to counter the biological activity of androgens is indicated. On the basis of the mechanism of action presented in Text-fig. 1, anti-androgens could exert their influence at two critical points; the formation of $5 \alpha$-dihydrotestosterone or alternatively, the formation and translocation of the $5 \alpha$-dihydrotestosteronereceptor complex.

Voigt \& Hsia (1973) have recently reported that 4-androsten-3-one-17 $\beta$ carboxylic acid can curtail the androgen-stimulated enlargement of the hamster costovertebral (flank) organ by selectively impairing $5 \alpha$-reductase activity and the formation of $5 \alpha$-dihydrotestosterone. Similar studies on rat prostate gland are awaited with interest.

Several anti-androgens are now available which prevent the formation of androgen-receptor complexes in the nucleus and abolish virtually all manifestations of the androgenic response. None of this group of compounds has significant effect on the metabolism of testosterone but they may limit the uptake of testosterone into accessory sex glands (Giorgi et al., 1973; Mainwaring et al., 1974a). Most compounds suppressing the formation of androgen receptor complexes are structurally related to androgenic steroids and the most intensively studied are cyproterone acetate (Fang \& Liao, 1969b) and BOMT (Mangan \& Mainwaring, 1972). They dramatically impair a wide spectrum of androgen-mediated biochemical responses in the prostate, including the stimulation of acid phosphatase activity (Geller et al., 1969), rRNA synthesis and nucleolar (form A) RNA polymerase activity (Mainwaring et al., 1971; Mangan \& Mainwaring, 1972), polyribosome synthesis (Mainwaring \& Wilce, 1973), poly (A)-rich mRNA synthesis (Mainwaring et al., 1974b) and polyamine synthesis (Mangan et al., 1973). It is significant that these compounds are unable to suppress the stimulation of glycolytic enzymes promoted by cyclic AMP or testosterone and this suggests that these enzymic changes are induced by metabolites of testosterone other than $5 \alpha$-dihydrotestosterone or indeed by testosterone itself.

Implicit to the receptor hypothesis is a close geometric fit between the specific binding site and the appropriate ligand. Accordingly, the structural homology between the steroid-related anti-androgens and $5 \alpha$-dihydrotestosterone is to be expected. Somewhat in conflict with this tenet of structural homo- 
logy, however, Neri \& Monahan (1972) reported that a non-steroidal aromatic compound, SCH 13521, could arrest canine prostatic hyperplasia. Nevertheless, it is now abundantly clear that SCH 13521 can curtail the high-affinity binding of $5 \alpha$-dihydrotestosterone in the prostatic nucleus (Mainwaring et al., 1974a; Liao et al., 1974; Neri et al., 1974) and the androgen-mediated increase in nucleolar RNA synthesis (Mainwaring et al., 1974a). It is not yet clear, however, whether SCH 13521 itself (see Text-fig. 2) or a metabolite is the actual antiandrogen in vivo. The ideal anti-androgen should be non-toxic, devoid of intrinsic hormonal activity and active at low concentrations and, since $\mathrm{SCH}$ 13521 satisfies these exacting criteria, it is likely to feature prominently in experimental work and also perhaps be a widely used chemotherapeutic agent.

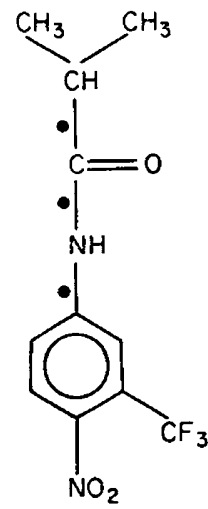

Text-Fig. 2. The non-steroidal anti-androgen, SCH 13521. The bonds marked • indicate points of free rotation, as predicted from Drieding models.

THE UBIQUITOUS IMPORTANGE OF THE FORMATION AND BINDING OF $5 \alpha$-DIHYDROTESTOSTERONE IN ACGESSORY SEX GLANDS

Mainwaring \& Mangan (1973) attempted to appraise whether 5 $\alpha$-dihydrotestosterone was critically important in the mechanism of action of androgens in the accessory sex glands of most common experimental animals. Representative data from this study are presented in Table 1. It is clear that all prostates do not invariably share a high $5 \alpha$-reductase activity in the adult animal. In keeping with earlier studies (Gloyna \& Wilson, 1969; Wilson \& Gloyna, 1970) a wide range of $5 \alpha$-reductase activity was found. Notwithstanding this, the highaffinity binding of $5 \alpha$-dihydrotestosterone was present in cytoplasmic extracts of all species investigated, including the rabbit, in which the reductase was barely detectable. Since appreciable $5 \alpha$-reductase is present in the prostate of immature and developing rabbits (Wilson \& Gloyna, 1970), it seems possible that the formation and binding of $5 \alpha$-dihydrotestosterone may only be of importance during periods of maximum prostatic development during the acquisition of sexual maturity, whereas in other species it must necessarily be formed throughout life. An unlikely alternative is that the prostate of the adult rabbit can operate at a threshold level of $5 \alpha$-dihydrotestosterone some two orders of magnitude lower than that of the rat. Developmental changes in 
$5 \alpha$-reductase activity are well known in organs other than the accessory sex glands, an excellent example being rat testis (Inano \& Tamaoki, 1966; Shikita \& Hall, 1967; Folman et al., 1973). Such modulations in androgen metabolism provide a subtle means whereby a given gland can provide different modes of androgenic stimuli dependent on the demands for growth or regeneration. A necessary corollary to this viewpoint is that $5 \alpha$-dihydrotestosterone must be considered the primary mitogenic agent for the prostate, as indeed seems the case (Wilson \& Gloyna, 1970).

Table 1. Variations in the ability of the prostates of some common laboratory animals to form and bind $5 \alpha$-dihydrotestosterone

\begin{tabular}{lcc}
\hline Source of prostate & $5 \alpha$-Reductase activity & Binding of $5 \alpha$-dihydrotestosterone \\
\hline & & \\
Rat & 100 & 100 \\
Mouse & $26 \cdot 1$ & $68 \cdot 6$ \\
Guinea-pig & $13 \cdot 7$ & $44 \cdot 1$ \\
Rabbit & $0 \cdot 6$ & 53.9 \\
\hline
\end{tabular}

\begin{abstract}
At appropriate times after castration, determinations were made of $5 \alpha$-reductase activity and the binding of $\left[{ }^{3} \mathrm{H}\right] 5 \alpha$-dihydrotestosterone. Determination of $5 \alpha$-reductase activity was conducted by incubation of whole tissue with $\left[{ }^{3} \mathrm{H}\right]$ testosterone as substrate; binding of $1 \mathrm{nM}$ $\left[{ }^{3} \mathrm{H}\right] 5 \alpha$-dihydrotestosterone was performed in cytoplasmic $100,000 \mathrm{~g}$ supernatant fractions and estimated by gel-exclusion chromatography on Sephadex G-200. Values are quoted with reference to findings in the rat set arbitrarily at 100; data are taken from Mainwaring \& Mangan (1973).
\end{abstract}

The evidence of Mainwaring \& Mangan (1973) is consistent with the ubiquitous presence of $5 \alpha$-dihydrotestosterone-specific androgen receptors since they were invariably demonstrated in the epididymis, seminal vesicle and preputial gland of all species investigated. Such receptors are also present in the human prostate (Hansson \& Tveter, 1971; Mainwaring \& Milroy, 1973).

\title{
MORE DETAILED INVESTIGATIONS INTO THE PROPERTIES OF PROSTATE CHROMATIN SUBFRAGTIONS INCLUDING THE BINDING OF RECEPTOR COMPLEXES
}

Reconstituted, cell-free systems for studying the transfer of receptor complexes into chromatin have been described (Mainwaring \& Peterken, 1971; Steggles et al., 1971). Prompted by the need for developing cell-free systems in which to investigate the regulation of genetic transcription by receptor complexes, it was necessary to improve these reconstituted systems containing chromatin and in particular to compare the properties of chromatin subfractions in vitro. There were earlier indications that androgens were predominantly bound within active chromatin (Mangan et al., 1968), formerly called euchromatin, but the full implications of the binding of $5 \alpha$-dihydrotestosterone were not fully appreciated at that time and the nature of this euchromatin-bound androgen was not unequivocally established. 
Using limited digestion with spleen DNase II, it is possible to prepare two subfractions of prostate chromatin (Table 2) which differ markedly in amount and chemical composition. For simplicity, these will be termed active and inactive chromatin; justification for this nomenclature will be apparent from the ensuing experimental findings. Inactive chromatin was the principal subfraction in terms of the recovery of DNA and was typified by a high histone content and a low content of non-histone protein. Conversely, active chromatin was present in small amounts but conspicuously enriched with respect to non-histone proteins. From time-course experiments at $37^{\circ} \mathrm{C}$, the relative amounts of active and inactive chromatin were not significantly affected by the duration of enzymic digestion. It should be emphasized that digestion of chromatin by spleen DNase II is extremely limited since the enzyme is operating at a $\mathrm{pH}$ far from its optimum

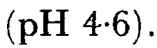

Table 2. The chemical composition of two subfractions of chromatin prepared by digestion with spleen DNase II

\begin{tabular}{|c|c|c|c|}
\hline \multirow[t]{2}{*}{ Chromatin subfraction } & \multirow{2}{*}{$\begin{array}{l}\text { Relative amounts } \\
\text { (in terms of } \% \\
\text { chromatin } D \mathcal{N A} \text { ) }\end{array}$} & \multicolumn{2}{|c|}{$\begin{array}{c}\text { Chemical composition } \\
\text { (with reference to } D \mathcal{N} A \text { as } 1 \cdot 0 \text { ) }\end{array}$} \\
\hline & & Histone protein & Non-histone protein \\
\hline $\begin{array}{l}\text { Inactive chromatin } \\
\text { (sedimented at } 30,000 \mathrm{~g} \text { ) }\end{array}$ & 84 to 89 & 1.21 to 1.38 & 0.94 to 0.96 \\
\hline $\begin{array}{l}\text { Active chromatin } \\
\text { (sedimented at } 100,000 \mathrm{~g} \text { ) }\end{array}$ & 11 to 16 & 0.11 to 0.18 & 1.26 to 1.38 \\
\hline
\end{tabular}

The enzymic digestion and the subsequent separation of the chromatin fractions were conducted as described in the 'Methods'. Chemical determinations were performed according to the method of Mainwaring \& Peterken (1971).

Active and inactive chromatin also differed in their ability to retain androgen receptor complexes in vitro (Text-fig. 3). Active chromatin bound at least twice the amount of receptor complex per unit amount of DNA than inactive chromatin (Text-fig. 3a). In addition, the specificity in the transfer process reported previously by Mainwaring \& Peterken (1971) was upheld in the present study, for spleen preparations bound far less receptor complex than prostate preparations (Text-fig. $3 \mathrm{~b}$ ). Finally, the mandatory presence of receptor protein in the transfer of $5 \alpha$-dihydrotestosterone was evident from the experimental controls (Text-fig. 3c); transfer did not occur in the presence of receptor-free extracts of spleen cytoplasm or with free $5 \alpha$-dihydrotestosterone.

Striking differences were also manifest in the ability of the prostate chromatin subfractions to serve as a template for RNA polymerase, including both heterologous (bacterial) and homologous (prostate, form B) enzyme (Text-fig. 4). This finding is consistent with the previous claims that histone-enriched chromatin is inactive or repressed in terms of template activity for RNA synthesis (Huang et al., 1964; Marushige \& Bonner, 1966).

The final distinguishing feature of the active prostate chromatin subfraction was that it essentially possessed all of the intrinsic chromatin-associated RNA polymerase activity; RNA polymerase activity could not be detected in inactive 


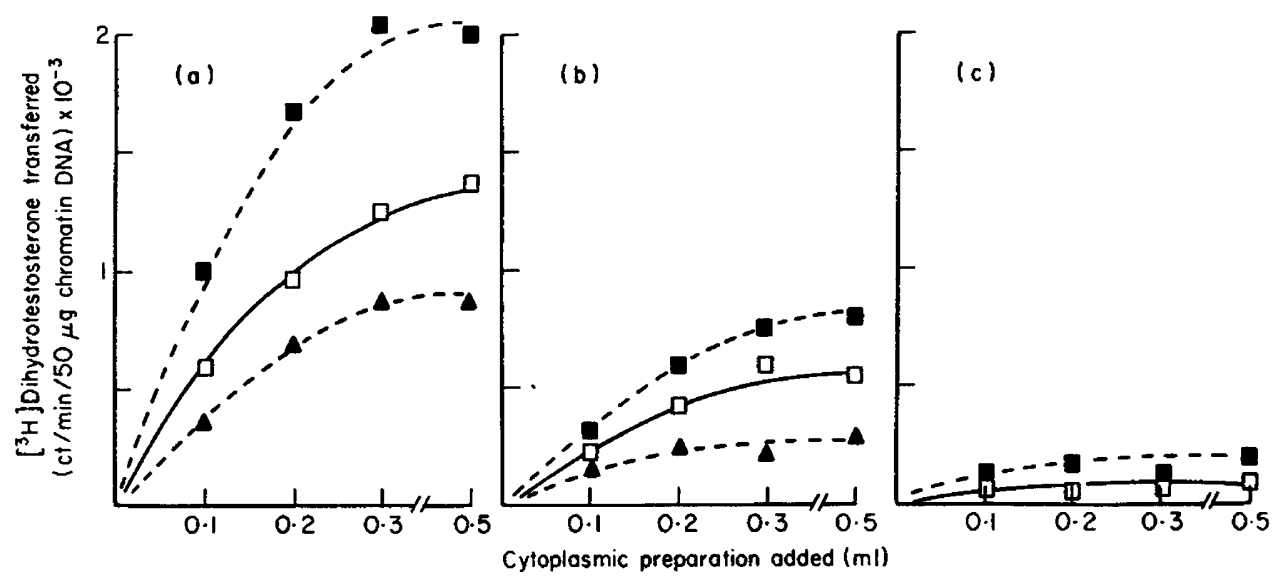

Text-FIG. 3. The transfer of $\left[{ }^{3} \mathrm{H}\right] 5 \alpha$-dihydrotestosterone into chromatin subfractions. Cytoplasmic extracts were prepared from tissues taken from rats castrated $24 \mathrm{hr}$ previously and incubated at $0^{\circ} \mathrm{C}$ with $3 \mathrm{nM}-\left[{ }^{3} \mathrm{H}\right] 5 \alpha$-dihydrotestosterone. After precipitation in $33 \%$ saturated $\left(\mathrm{NH}^{3}\right)_{2} \mathrm{SO}_{4}$, prostate preparations were redissolved to yield $7000 \mathrm{ct} / \mathrm{min}$ of $\left[{ }^{3} \mathrm{H}\right]$ dihydrotestosterone $/ 0.5 \mathrm{ml}$. Samples of spleen cytoplasm were similarly treated. Graded amounts of cytoplasmic preparations were incubated with chromatin subfractions and the transfer of radioactivity into chromatin was determined. (a) Cytoplasm and chromatin from prostate. $\square$, Active chromatin; $\square$, total (unfractionated) chromatin; $\Delta$, inactive chromatin. (b) Prostate cytoplasm and spleen chromatin. $\mathbf{\square}$, Active chromatin; $\square$, total chromatin; $\Delta$, inactive chromatin. (c) Active prostate chromatin and spleen cytoplasm or free $\left[{ }^{3} \mathrm{H}\right] 5 \alpha$-dihydrotestosterone (up to $7000 \mathrm{ct} / \mathrm{min}$ ). $\mathbf{m}$, Spleen cytoplasm; $\square$, free $\left[{ }^{3} \mathrm{H}\right]$ dihydrotestosterone.

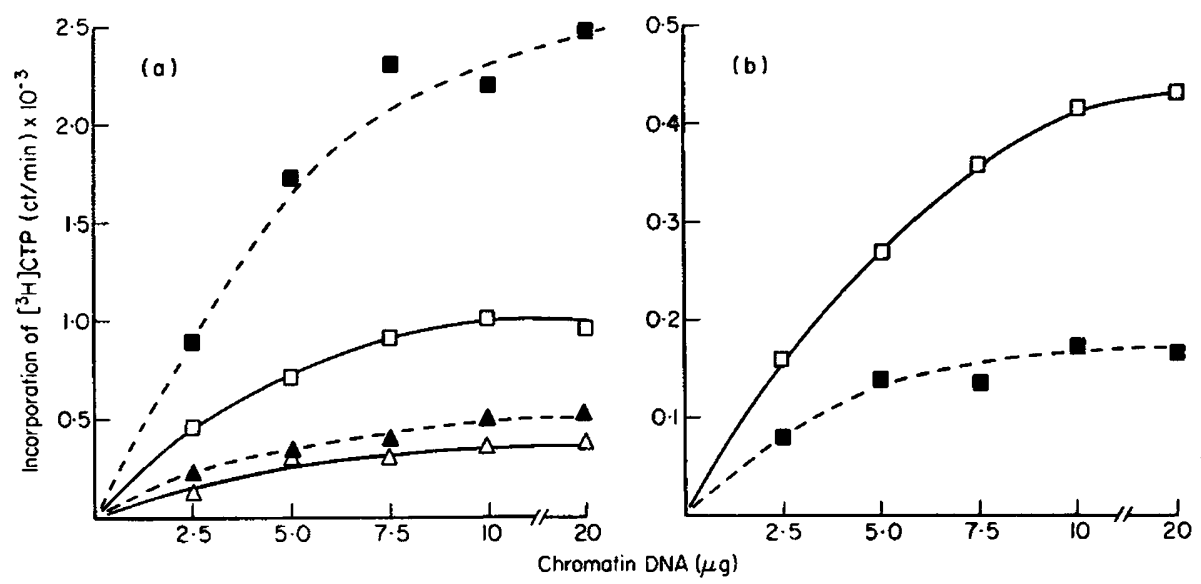

TEXT-FIG. 4. The transcription of prostate chromatin subfractions by RNA polymerases. Increasing amounts of chromatin subfractions were incubated with purified RNA polymerases and the incorporation of $\left[{ }^{3} \mathrm{H}\right] \mathrm{CTP}$ into RNA was determined. (a) $E$. coli RNA polymerase. $\square$, Prostate DNA; $\square$, active chromatin; $\Delta$, total (unfractionated chromatin); $\triangle$, inactive chromatin. (b) Prostate form $B$ polymerase. $\square$, Active chromatin; $\boldsymbol{b}$, inactive chromatin. At all chromatin concentrations, the incorporation of $\left[{ }^{3} \mathrm{H}\right] \mathrm{CTP}$ was corrected for endogenous activity in the absence of added exogenous enzyme. 
chromatin (Table 3). Harmonious with the reports of other investigators (Butterworth et al., 1971), the RNA polymerase activity was enhanced in conditions of high ionic strength and was totally dependent on the presence of divalent cations and complementary nucleoside $5^{\prime}$-triphosphates. The RNA polymerase associated with chromatin was clearly of the B form since it was inhibited by $\alpha$-aminitin.

Overall, these findings indicate that receptor complexes are preferentially retained in histone-depleted chromatin, as had been suggested formerly using an entirely different experimental approach (Mainwaring \& Peterken, 1971). Use of systems based on the active and inactive prostate chromatin subfractions should enable a more penetrating insight to be gained into the means by which receptor complexes regulate the transcription of chromatin.

Table 3. The endogenous RNA polymerase activity associated with prostate chromatin subfractions

\begin{tabular}{|c|c|c|c|}
\hline Experiment & Type of chromatin & Assay conditions & $\begin{array}{c}\text { Ct/min incorporated } / 30 \text { min at } \\
37^{\circ} \mathrm{C} / 250 \mu \mathrm{g} \text { chromatin DNA } \\
(\text { Mean } \pm \text { S.E.M. })\end{array}$ \\
\hline $\begin{array}{l}\text { Comparison of } \\
\text { activities in chromatin } \\
\text { subfractions }\end{array}$ & $\begin{array}{l}\text { Unfractionated material } \\
\text { Inactive chromatin } \\
\text { Active chromatin }\end{array}$ & Standard & $\begin{array}{c}60 \pm 7 \\
70 \pm 11 \\
610 \pm 30\end{array}$ \\
\hline $\begin{array}{l}\text { Characterization of } \\
\text { enzyme activity }\end{array}$ & $\begin{array}{l}\text { Active chromatin } \\
\text { throughout }\end{array}$ & $\begin{array}{l}\text { Standard } \\
0 \cdot 1 \mathrm{M}-\left(\mathrm{NH}_{4}\right)_{2} \mathrm{SO}_{4} \\
\text { Absence of }\left(\mathrm{NH}_{4}\right)_{2} \mathrm{SO}_{4} \\
\text { Minus } \mathrm{Mg}^{2+} \text { and } \mathrm{Mn}^{2+} \\
\text { Minus nucleoside } \\
5^{\prime} \text {-triphosphates } \\
\text { Plus } \alpha \text {-aminitin }(5 \mu \mathrm{g})\end{array}$ & $\begin{array}{l}627 \pm 21 \\
310 \pm 34 \\
41 \pm 7 \\
30 \pm 3 \\
66 \pm 16 \\
41 \pm 4\end{array}$ \\
\hline
\end{tabular}

Prostate chromatin was fractionated as described in the 'Methods' and chromatin-associated RNA polymerase was measured in the conditions recommended by Butterworth et al. (1971); [ $\left.{ }^{3} \mathrm{H}\right] \mathrm{CTP}$ was used as labelled nucleoside $5^{\prime}$-triphosphate $(2 \cdot 0 \mu \mathrm{Ci} /$ assay; $9 \cdot 1 \mathrm{Ci} / \mathrm{mmol})$ and each assay contained 40 to $120 \mu \mathrm{g}$ of chromatin DNA. All assays were conducted in the presence of $0.2 \mathrm{M}-\left(\mathrm{NH}_{4}\right)_{2} \mathrm{SO}_{4}$ unless specified otherwise.

EVIDENGE THAT ANDROGENS REGULATE THE SYNTHESIS OF MRNA

IN THE PROSTATE

Although the mechanism of action of androgens is superficially similar in many androgen-sensitive tissues, subtle differences in the androgenic response are well documented. For example, androgens can induce the synthesis of alcohol dehydrogenase in certain tissues and not others (Ohno et al., 1970; furthermore, certain accessory sex glands secrete very large amounts of citric acid whereas others secrete exclusively fructose (Samuels et al., 1962). To accommodate these differences, it could be argued that structurally distinct androgen receptors exist in different accessory sexual glands and that by interaction with specific, indeed unique, regions of the genome, these promote the synthesis of species of mRNA coding for distinctive proteins or enzymes. Alternatively, the receptors may be essentially similar in structure but tissueand species-sepecific differences in chromatin-associated proteins may restrict the binding of receptor complexes to specific areas in chromatin, thereby 
regulating the synthesis of mRNA. Whichever proves correct, it is evident that a deeper understanding of the androgenic regulation of $m R N A$ synthesis was required. It has been shown that androgens do in fact control the synthesis of poly (A)-rich mRNA in the prostate gland in a stringently tissue- and steroidspecific manner (Mainwaring et al., 1974b).

\section{The androgenic control of prostatic aldolase}

As a continuation of the study of Mainwaring et al. (1974b), it was desirable to examine the androgenic control of the synthesis of a specific mRNA coding for a well-defined constituent of the prostate gland. Aldolase was selected on several grounds; first, its activity is subject to regulation by testosterone (Butler \& Schade, 1958) and second, it may be readily purified and crystallized to homogeneity (Gracy et al., 1970).

Methods. The procedures used in this study have been described elsewhere. Nuclei and chromatin were isolated according to the methods of Mainwaring \& Peterken (1971). Fractionation of chromatin was accomplished by digestion with spleen deoxyribonuclease II as described by Marushige \& Bonner (1971). Chromatin (400 to $500 \mu \mathrm{g} \mathrm{DNA} / \mathrm{ml})$ was resuspended in $10 \mathrm{~mm}$-tris- $\mathrm{HCl}$ buffer, pH 8.0 , containing $1 \mathrm{~mm}$-EDTA and incubated at $37^{\circ} \mathrm{C}$ for $1 \mathrm{hr}$ with DNase $(50 \mu \mathrm{g} / \mathrm{ml})$. After clarification of the digest by centrifugation at $10,000 \mathrm{~g}$ for $10 \mathrm{~min}$, the supernatant was made $0.15 \mathrm{M}$ with respect to $\mathrm{NaCl}$ (added dropwise in $50 \mathrm{~mm}$-citrate buffer, $\mathrm{pH} \mathrm{7.0)}$ and the two chromatin subfractions were recovered by differential centrifugation. Inactive chromatin was first sedimented at $30,000 \mathrm{~g}$ and active chromatin at $100,000 \mathrm{~g}$ (Marushige \& Bonner, 1971). Polyribosomes were isolated by the procedure recommended by Mainwaring \& Wilce (1973). Poly (A)-rich mRNA was isolated by chromatography on oligo(dT) cellulose (Mainwaring et al., 1974b). Cytoplasmic extracts (cell $100,000 \mathrm{~g}$ supernatant fractions) were labelled with $3 \mathrm{~nm}$ $\left[1,2-{ }^{3} \mathrm{H}\right] 5 \alpha$-dihydrotestosterone (17 $\beta$-hydroxy- $5 \alpha$-androstan-3-one, $47 \mathrm{Ci} / \mathrm{mmol}$; Radiochemical Centre, Amersham, Bucks), and partly purified androgen receptor complex was precipitated by dropwise addition of saturated $\left(\mathrm{NH}_{4}\right)_{2}-$ $\mathrm{SO}_{4}$ (Enzyme grade, Fisons Ltd, Loughborough, Leics., titrated to $\mathrm{pH} 7 \cdot 4$ with $\mathrm{NH}_{4} \mathrm{OH}$ ) to an overall saturation of $33 \%$ (Mainwaring \& Peterken, 1971). Prostate RNA polymerase (form B enzyme; $\alpha$-amanitin sensitive) was substantially purified by ion-exchange chromatography on DEAE-Sephadex (Mainwaring et al., 1971). Escherichia coli RNA polymerase was isolated from strain MRE 600 (ribonuclease-free mutant) according to the procedure of Burgess (1969). The assay system for measurement of RNA polymerase activity was that described by Mainwaring et al. (1971). Preparations of the proteinsynthesizing system derived from Krebs II ascites-tumour cells were generously provided by my colleague, Dr A. E. Smith. The transfer of $\left[{ }^{3} \mathrm{H}\right] 5 \alpha$-dihydrotestosterone into chromatin in reconstituted cell-free systems was accomplished under the conditions established by Mainwaring \& Peterken (1971). Determination of the activity of NADPH-dependent 3-oxosteroid 5 $\alpha$-reductase was conducted by the procedure of Mainwaring \& Mangan (1973). Anti-androgens were kindly supplied by pharmaceutical companies: cyproterone acetate $(6 \alpha-$ chloro-1 $7 \alpha$-hydroxy-1 $\alpha, 2 \alpha$-methylene-4,6-pregnadien-3,20-dione) by Schering 
Ltd, Burgess Hill, Sussex; BOMT (6 $\alpha$-bromo-17 $\alpha$-methyl-17 $\beta$-hydroxy-4-oxa$5 \alpha$-androstan-3-one) by Hoffman La Roche, Basle, Switzerland and SCH 13521 (4'-nitro-3'-trifluoromethylisobutrylanilide) by Schering Corp., Bloomfield, N.J., U.S.A. Grystalline aldolase was isolated and finally crystallized from rat prostate gland by the method of Gracy et al. (1970). Antibodies against crystalline aldolase were raised in rabbits (Mainwaring et al., 1974c) and rigorously tested for the quantitative precipitation of the crystalline enzyme. This will be referred to as anti-aldolase serum; control serum was taken from the rabbits before their immunological challenge with prostate aldolase.

Table 4. The precipitation of labelled aldolase after the incubation of ascites-tumour protein synthesizing system with poly (A)-rich mRNA

\begin{tabular}{lccc}
\hline Source of the mRNA & $\begin{array}{c}\text { Total incorporation } \\
(\text { ct/min) }\end{array}$ & \multicolumn{2}{c}{ Precipitated radioactivity (ct/min) } \\
\cline { 3 - 4 } & & Anti-aldolase serum & Control serum \\
\hline None (controls) & $8400 \pm 290$ & $55 \pm 8$ & $66 \pm 6$ \\
Rabbit reticulocytes & $30800 \pm 1100$ & $107 \pm 11$ & $99 \pm 4$ \\
Rat prostate & $20900 \pm 400$ & $329 \pm 20$ & $130 \pm 21$ \\
Rat liver & $17800 \pm 380$ & $149 \pm 4$ & $101 \pm 11$ \\
Rat muscle & $14100 \pm 240$ & $194 \pm 2$ & $100 \pm 1$ \\
\hline
\end{tabular}

Values are Means \pm S.E.M.

As described by Mainwaring, Wilce \& Smith (1974), protein synthesis was conducted in cell-free system in vitro (total vol. $50 \mu \mathrm{l}$ containing $2.5 \mu \mathrm{Ci}\left[{ }^{3} \mathrm{H}\right]$ phenylalanine) in the presence of $2.5 \mu \mathrm{g}$ poly (A)-rich mRNA. At the completion of incubation, samples were removed from each assay to assess the total incorporation of radioactivity into peptide linkage. The remainder was halved and treated with either specific anti-aldolase or control serum in order to determine the radioactivity in the form of aldolase. The data are taken from Mainwaring ot al. $(1974 \mathrm{c})$.

Results. Using rabbit antibodies raised against crystalline prostatic aldolase, a simplified means of identifying the enzyme synthesized in polyribosomes in vivo or in cell-free systems in vivo was available. The rabbit anti-aldolase serum was highly specific in that it effectively precipitated only purified prostatic aldolase; it was able partly to precipitate muscle aldolase but was essentially unreactive against liver aldolase. Furthermore, it was unable to precipitate other prostate enzymes such as alkaline phosphatase and glucose-6-phosphate dehydrogenase (Mainwaring et al., 1974c).

A sensitive system was developed for the assay of as little as $1 \mu \mathrm{g}$ of prostate poly (A)-rich mRNA in a protein-synthesizing system derived from Krebs II ascites-tumour cells (Mainwaring et al., 1974c). Using the specific anti-aldolase serum it was possible to demonstrate an acute tissue specificity in the source of mRNA for synthesizing prostate aldolase in cell-free systems in vitro (Table 4). Radioactivity was selectively precipitated from incubations of ascites-tumour preparations in the presence of prostate mRNA but not that from liver or reticulocytes; some radioactivity was precipitated selectively from syntheses conducted in the presence of muscle mRNA. This is not surprising, since muscle and prostate aldolase are structurally related (Mainwaring et al., 1974c). 
In a further experiment, the tissue specificity of the androgenic regulation of prostate mRNA synthesis was investigated. Castrated animals received testosterone in vivo and, at various times thereafter, the poly (A)-rich mRNA was isolated from the prostate and liver. This was then added at a constant amount $(2.5 \mu \mathrm{g})$ to the ascites-tumour protein-synthesizing system and the synthesis of aldolase was monitored immunologically (Table 5). Only in the prostate was it possible to demonstrate a significant increase of aldolase synthesis after androgenic stimulation. This reached a maximum at 8 to $16 \mathrm{hr}$ and then declined.

An investigation was also made of the steroid specificity of the prostatic aldolase mRNA synthesis. Rather than using cell-free systems in vitro for

Table 5. The tissue specificity in the androgenic regulation of aldolase on RNA synthesis

\begin{tabular}{ccccc}
\hline \multirow{2}{*}{ Source of mRNA } & Testosterone treatment & Total incorporation & \multicolumn{2}{c}{ Precipitated radioactivity $(c t / m i n)$} \\
\cline { 3 - 5 } & & (ct/min) & Anti-aldolase serum & Control serum \\
\hline Prostate & None (controls) & $17190 \pm 200$ & $132 \pm 21$ & $66 \pm 10$ \\
& 4 & $18490 \pm 110$ & $251 \pm 17$ & $120 \pm 18$ \\
& 8 & $22100 \pm 270$ & $349 \pm 21$ & $140 \pm 13$ \\
& 16 & $21000 \pm 120$ & $260 \pm 17$ & $111 \pm 20$ \\
Liver & 24 & $20340 \pm 240$ & $167 \pm 20$ & $106 \pm 17$ \\
& None (controls) & $15500 \pm 190$ & $170 \pm 20$ & $87 \pm 8$ \\
& 4 & $16200 \pm 170$ & $180 \pm 17$ & $94 \pm 7$ \\
& 8 & $16000 \pm 240$ & $168 \pm 13$ & $86 \pm 6$ \\
& 16 & $16400 \pm 120$ & $181 \pm 17$ & $94 \pm 10$ \\
& 24 & $16200 \pm 140$ & $174 \pm 16$ & $106 \pm 6$ \\
\hline
\end{tabular}

Values are Means \pm S.E.M.

Forty rats were castrated and $96 \mathrm{hr}$ after the operation the animals received a subcutaneous injection of $2.5 \mathrm{mg}$ testosterone phenylpropionate; eight animals served as controls and received an injection of oil only. At intervals, the poly (A)-rich mRNA was isolated from tissue pooled from eight animals and $2.5 \mu \mathrm{g}$ was added to the ascites-tumour proteinsynthesizing system. The products were analysed for aldolase as described in the legend to Table 4. The data are taken from Mainwaring et al. (1974c).

Table 6. The steroid specificity of the regulation of aldolase mRNA synthesis

\begin{tabular}{lccc}
\hline & & \multicolumn{2}{c}{ Precipitated radioactivity $(c t / m i n / 500 \mu \mathrm{g} R \mathcal{N} A)$} \\
\cline { 3 - 4 } Hormonal treatment & $\begin{array}{c}\text { Total incorporation } \\
(c t / m i n / 500 \mu g R \mathcal{H})\end{array}$ & Anti-aldolase serum & Control serum \\
\hline & & & \\
None (controls) & $4220 \pm 300$ & $120 \pm 12$ & $106 \pm 6$ \\
Testosterone & $8290 \pm 340$ & $330 \pm 21$ & $179 \pm 19$ \\
Oestradiol-17 $\beta$ & $3140 \pm 70$ & $104 \pm 7$ & $120 \pm 20$ \\
Corticosterone & $4520 \pm 290$ & $56 \pm 21$ & $71 \pm 19$ \\
\hline
\end{tabular}

Values are Means \pm S.E.M.

At $96 \mathrm{hr}$ after castration, thirty-two rats were injected subcutaneously with $2.5 \mathrm{mg}$ various steroids; eight rats were controls and received injections of oil only. After $16 \mathrm{hr}$ of hormonal treatment, $5 \mu \mathrm{Ci}\left[{ }^{35} \mathrm{~S}\right]$ methionine was injected directly into the prostates and labelled polyribosomes were isolated 15 min later (Mainwaring \& Wilce, 1973). The polyribosomes were analysed for labelled aldolase as described in the legend to Table 4. The data are taken from Mainwaring et al. (1974c). 
monitoring protein synthesis, polyribosomes were labelled in vivo by the injection of $\left[{ }^{35} \mathrm{~S}\right]$ methionine directly into the prostate (Mainwaring \& Wilce, 1973). Taking the time necessary to reach a maximum in the response of aldolase mRNA synthesis of some $16 \mathrm{hr}$ (see Table 5), castrated animals were injected with various steroids. At $16 \mathrm{hr}$ after the beginning of treatment, prostate polyribosomes were labelled and analysed for aldolase by immunological means. Only androgens were able to enhance the synthesis of aldolase mRNA in vivo (Table 6), indicating the marked steroid specificity of this response.

In conclusion, aldolase proved to be a suitable marker for following the androgenic control of the synthesis of a specific poly (A)-rich mRNA in the prostate gland. The synthesis of prostate aldolase mRNA was very rigidly controlled both in terms of tissue and steroid specificity. This work provided a far more sophisticated insight into prostate mRNA synthesis than was possible in our earlier study (Mainwaring et al., 1974b).

\section{ACKNOWLEDGMENT}

The author wishes to acknowledge the assistance of Mrs Margaret Barker in the preparation of the manuscript.

\section{REFERENCES}

ANDERson, K.M. \& LiAo, S. (1968) Selective retention of dihydrotestosterone by prostatic nuclei. Nature, Lond. 219, 277-279.

Artman, M. \& Roth, J.S. (1971) Chromosomal RNA; an artefact of preparation? F. molec. Biol. 60, 291-301.

Bauliev, E-E., LAsnitzki, I. \& Robel, P. (1968) Metabolism of testosterone and action of metabolites on prostate glands grown in organ culture. Nature, Lond. 219, 1155-1156.

Baulieu, E-E., Jung, I., Blondeau, J.P. \& Robei, P. (1971) Androgen receptors in rat ventral prostate gland. Adv. Biosci. 7, 179-191.

BRUCHOVSKY, N. (1971) Comparison of metabolites formed in rat prostate following the in vivo administration of seven natural androgens. Endocrinology 89, 1212-1222.

Burgess, R.R. (1969) A new method for the large-scale preparation of Escherichia coli deoxyribonucleic acid-dependent ribosenucleic acid polymerase. 7. biol. Chem. 244, 6160-6167.

Butler, W.W.S. \& SCHADE, A.L. (1958) Effects of castration and androgen replacement on the nucleic acid composition, metabolism and enzymatic capacities of the rat ventral prostate. Endocrinology 63, 271-279.

Butterworth, P.H.W., Cox, R.F. \& Chesterton, C.J. (1971) Transcription of mammalian chromatin by mammalian DNA-dependent RNA polymerase. Eur. F. Biochem. 23, 229-241.

de Moor, P., Steeno, O., Heyns, W. \& van Baelen, H. (1969) The steroid binding $\beta$-globulin in plasma: pathophysiological data. Annls Endocr. 30, 233-236.

Dorfman, R.I. \& Shipley, R.A. (1956) Androgens, pp. 3-9. Wiley, New York.

FANG, S. \& LLAo, S. (1969a) Androgen receptors. F. biol. Chem. 246, 16-24.

FANG, S. \& LIAO, S. (1969b) Antagonistic action of anti-androgens on the formation of a specific dihydrotestosterone-receptor protein complex in the rat ventral prostate. Molec. Pharmacol. 5, $428-432$.

Folman, Y., Ahman, N., Sowell, J.G. \& Eik-Nes, K.B. (1973) Formation in vitro of $5 \alpha$-dihydrotestosterone and other $5 \alpha$-reduced metabolites of ${ }^{3} \mathrm{H}$-testosterone by semiferous tubules and interstitial tissue from immature and mature rat testes. Endocrinology 92, 41-47.

Furuyama, S., Mayes, D. \& Nugent, C.A. (1970) A radioimmune assay for plasma testosterone. Steroids 16, 415-428.

Geller, J., van Damme, O., Garabieta, G., Lok, A., Rettura, J. \& Seifter, E. (1969) Effect of cyproterone acetate on ${ }^{3} \mathrm{H}$-testosterone uptake and enzyme synthesis by the ventral prostate of the rat. Endocrinology 84, 1330-1335.

Georgiev, G.P. (1972) Informosomes. Curr. Topics devl Biol. 7, 1-24.

Giorgi, E.P., Stewart, J.C., Grant, J.K. \& Shirley, I.M. (1972) Androgen dynamics in vitro in the human prostate gland. Biochem. F. 126, 107-121. 
Grorgi, E.P., Shirley, I.M., Grant, J.K. \& Stewart, J.C. (1973) Androgen dynamics in vitro in the human prostate gland. Biochem. F. 132, 465-474.

Gloyna, R.E. \& Wilson, J.D. (1969) A comparative study of the conversion of testosterone to $17 \beta$ hydroxy-5 $\alpha$-androstan-3-one (dihydrotestosterone) by prostate and epididymis. J. clin. Endocr. Metab. 29, 970-911.

Gracy, R.W., LAcko, A.G., Brox, L.W., Adelman, R.G. \& Horecker, B.L. (1970) Structural relations in aldolases purified from rat liver and muscle and Novikoff hepatoma. Archs Biochem. Biophys. 136, $480-490$.

Hansson, V. \& TVETER, K.J. (1971) Effect of anti-androgens on the uptake and binding of androgen by human benign nodular prostatic hyperplasia in vitro. Acta endocr., Copenh. 68, 29-78.

Heyden, H.W. \& ZAGHav, H.G. (1971) Characterization of RNA fractions of calf thymus chromatin. Biochim. biophys. Acta 232, 651-660.

Huang, R-C.C., Bonner, J. \& Murray, K. (1964) Physical and biological properties of soluble nucleohistones. 7. molec. Biol. 8, 54.

Inano, H. \& TAMAoxI, B-I. (1966) Conversion of steroids in immature rat testis in vitro. Endocrinology $79,579-590$.

Ito, T. \& Horton, R. (1970) A new androgen in human plasma. Clin. Res. 18, 122.

Kato, T. \& HoRt on, R. (1968) Studies on testosterone binding globulin. F. clin. Endocr. Metab. 28, 1160.

KING, R.J.B. (1972) Control of oestrogen action by specific oestrogen-protein interaction. In Effects of Drugs on Cellular Control Mechanisms, pp. 11-26. Eds. B. R. Rabin and R. B. Freedman. Macmillan, London.

King, R.J.B. \& Mainwaring, W.I.P. (1974) Steroid Cell Interactions. Butterworths Medical Publications, London.

Liao, S., Liang, T. \& Tymoczko, J.L. (1973) Ribonucleoprotein binding of steroid-"receptor" complexes. Nature, New Biol. 241, 211-213.

Liao, S., Howell, D.K. \& Ghang, T.-M. (1974) Action of non-steroidal anti-androgen, flutamide, on the receptor binding and nuclear retention of 5-dihydrotestosterone in rat ventral prostate. Endocrinology 94, 1205-1209.

Mainwaring, W.I.P. (1971) Androgen receptors. In Some Aspects of the Aetiology and Biochemistry of Prostatic Cancer, pp. 109-114. Eds. K. Griffiths and C. G. Pierrepoint. Alpha Omega Alpha, Cardiff.

Mainwaring, W.I.P. \& Inving, R.A. (1973) The use of deoxyribonucleic acid- cellulose chromatography and isoelectric focusing for the characterization and partial purification of steroid-receptor complexes. Biochem. F. 134, 113-127.

Mainwaring, W.I.P. \& Mangan, F.R. (1973) A study of the androgen receptors in a variety of androgen-sensitive tissues. $\mathcal{F}$. Endocr. 59, 121-139.

Mainwaring, W.I.P. \& Mil.roy, E.J.G. (1973) Characterization of the specific androgen receptors in the human prostate gland. F. Endocr. 57, 371-384.

Mainwaring, W.I.P. \& Peterken, B.M. (1971) A reconstituted cell-free system for the specific transfer of steroid-receptor complexes into nuclear chromatin isolated from rat ventral prostate gland. Biochem. F. 125, 285-295.

Mainwaring, W.I.P. \& WIIcE, P.A. (1973) The control of the form and function of the ribosomes in androgen-dependent tissues by testosterone. Biochem. F. 134, 795-805.

Mainwaring, W.I.P., Mangan, F.R. \& Peterken, B.M. (1971) Studies on the solubilized ribonucleic acid polymerase from rat ventral prostate gland. Biochem. F. 123, 619-628.

Mainwaring, W.I.P., Mangan, F.R., Feherty, P.A. \& Friefeld, M. (1974a) An investigation into the anti-androgenic properties of the non-steroidal compound, SCH 13521 (4'-nitro-3'-trifluoromethylisobutyrlanilide). Molec. cell. Endocr. 1, 113-128.

Mainwaring, W.I.P., Wilce, P.A. \& Smith, A.E. (1974b) Studies on the form and synthesis of messenger ribonucleic acid in the rat ventral prostate gland, including its tissue-specific stimulation by androgens. Biochem. F. 137, 513-524.

Mainwaring, W.I.P., Mangan, F.R., Irving, R.A. \& Jones, D.M. (1974c) Specific changes in the messenger RNA content of rat ventral prostate gland after androgenic treatment, evidence from the synthesis of aldolase messenger RNA. Biochem. F. 144, 413-426.

Mangan, F.R. \& Mainwaring, W.I.P. (1972) An explanation of the anti-androgenic properties of $6 \alpha$-bromo-1 7 $\beta$-hydroxy-17 $\alpha$-methyl-4-oxa-5 $\alpha$-androstane-3-one. Steroids 20, 331-343.

Mangan, F.R., Neal, G.E. \& Williams, D.C. (1968) Subcellular distribution of testosterone in rat prostate and its possible relationship to nuclear ribonucleic acid synthesis. Archs Biochem. Biophys. 124, 27-40.

Mangan, F.R., PegG, A.E. \& Mainwaring, W.I.P. (1973). A reappraisal of the effects of adenosine $3^{\prime}: 5^{\prime}$-cyclic monophosphate on the function and morphology of the rat prostate gland. Biochem. $\mathcal{F}$. $134,129-142$. 
Marushige, K. \& Bonner, J. (1966) Template properties of liver chromatin. J. molec. Biol. 15, $160-174$. Marushige, K. \& Bonner, J. (1971) Fractionation of liver chromatin. Proc. natn. Acad. Sci. U.S.A. 68, 2941-2944.

Murphy, B.E.P. (1968) Binding of testosterone and estradiol in plasma. Can. J. Biochem. 46, $299-302$.

Neri, R. \& Monahan, M. (1972) Effects of a novel nonsteroidal anti-androgen in canine prostatic hyperplasia. Investve Urol. 10, 123-130.

Neri, R., Florance, K., Koziol, P. \& van Gleave, S. (1974) A biological profile of a nonsteroidal anti-androgen, SCH 13521 (4'-nitro-3'-trifluoromethylisobutyrlanilide). Endocrinology 91, 427437.

Ohno, S., Stenius, S., Christian, L., Harris, C. \& Ivey, C. (1970) More about the testosterone induction of kidney alcohol dehydrogenase activity in the mouse. Biochem. Genet. 4, 565-577.

RENNIE, P. \& BRuchovsky, N. (1972) In vitro and in vivo studies on the functional significance of androgen receptors in rat prostate. 7 . biol. Chem. 247, 1546-1554.

Roy, A.K., Baulieu, E-E., Feyel-Cabanes, T., le Goascogne, C. \& Robel, P. (1972a) Hormone metabolism and action. II. Androstenedione in prostate organ culture. Endocrinology 91, 396-403.

Roy, A.K., Robel, P. \& BAulieu, E-E. (1972b) Hormone metabolism and action. III. Metabolism of $3 \alpha$-hydroxy and $3 \beta$-hydroxy C19 steroids in prostate organ culture. Endocrinology 91, 404-408.

Samuels, L.T., Harding, B.W. \& Mann, T. (1962) Aldose reductase and ketose reductase in male accessory organs of reproduction. Biochem. 7. 84, 39-45.

Shrkita, M. \& Hall, P.F. (1967) The action of human chorionic gonadotrophin in vivo upon microsomal enzymes of the immature rat testis. Biochim. biophys. Acta 136, 484-497.

Singhal, R.L., Parvlekar, M.R., Vijayvargiya, R. \& Robison, G.A. (1971) Metabolic control mechanisms in mammalian systems. Biochem. F. 125, 329-342.

Strggles, A.W., Spelsberg, T.C., Glasser, J.R. \& O’Malley, B.W. (1971) Soluble complexes between steroid hormones and target-tissue receptors bind specifically to target-tissue chromatin. Proc. natn. Acad. Sci. U.S.A. 68, 1479-1482.

Tremblay, E.R., Bertins, I.Z., Kowarski, A. \& Mrgeon, C.J. (1970) Measurement of plasma dihydrotestosterone by competitive protein-binding proteins. Steroids $16,29-40$.

Tremblay, R.R., Forest, R.G., Shalf, J., Martel, J.G., Kowarski, A. \& Migeon, G.J. (1972) Studies on the dynamics of androgens and on the origin of dihydrotestosterone in dogs, Endocrinology 91, 556-561.

UNHJEM, O. \& TVETER, K.J. (1969) Localisation of an androgen binding substance from the rat ventral prostate. Acta endocr., Copenh. 60, 571-578.

Vermeulen, A. \& Verdonck, L. (1968) Studies on the binding of testosterone to human plasma. Steroids 11, 609-635.

Vorgt, W. \& HsiA, S.L. (1973) The antiandrogenic action of 4-androsten-3-one-17 $\beta$-carboxylic acid and its methyl ester on human hamster flank organ. Endocrinology 92, 1216-1222.

Wilson, J.D. \& Gloyna, R.E. (1970) The intranuclear metabolism of testosterone in the accessory organs of reproduction. Recent Prog. Horm. Res. 26, 309-336.

\section{NOTE ADDED IN PROOF}

Important new evidence on the proteinaceous nature of the nuclear acceptor sites is now available (Puca et al., 1974). In addition, there are indications of a release or exit mechanism for $5 \alpha$-dihydrotestosterone (Kirdani et al., 1972; Giorgi et al., 1974).

\section{REFERENCES}

Grorgi, E.P., Moses, T.F., Grant, J.K., Scott, R. \& SinclaIr, J. (1974) In vitro studies of the regulation of androgen-tissue relationships in normal canine and hyperplastic human prostate. Molec. cell. Endocr. 1, 271-284.

Kirdani, R.Y., Varkarakis, M.J., Murphy, G.P. \& Sandberg, A.A. (1972) Distribution of simuftaneously injected androgens and estrogens in animal tissues. Endocrinology 90, 1245-1251.

PucA, G.A., SicA, V. \& NolA, E. (1974) Identification of a high affinity nuclear acceptor site for estrogen receptor in rat uterus. Proc. natn. Acad. Sci. U.S.A. 71, 979-983. 